\title{
The presence of $\mathrm{CD}^{+}$invariant NKT cells in mice
}

Hyunji Lee ${ }^{1}$, Changwan Hong ${ }^{1}$, Junghoon Shin', Soohwan Oh', Sundo Jung ${ }^{1}$, Yoon-Kyung Park', Seokmann Hong ${ }^{2}$, Gap Ryol Lee ${ }^{3}$ and Se-Ho Park ${ }^{1,4}$

${ }^{1}$ School of Life Sciences and Biotechnology

Korea University

Seoul 136-701, Korea

${ }^{2}$ Department of Biosciences and Biotechnology

Sejong University

Seoul 143-747, Korea

${ }^{3}$ Department of Life Science

Sogang University

Seoul 121-742, Korea

${ }^{4}$ Corresponding author: Tel, 82-2-3290-3160;

Fax, 82-2-927-9028; E-mail, sehopark@korea.ac.kr

DOI 10.3858/emm.2009.41.12.092

Accepted 27 July 2009

Abbreviations: $\alpha$-GalCer, $\alpha$-galactosylceramide; $D N, \quad C D 4 / C D 8$ double negative; DP, CD4/CD8 double positive; Veh, vehicle

\begin{abstract}
Invariant natural killer T (iNKT) cells develop in the thymus upon recognition of CD1d expressed on developing thymocytes. Although CD4 and CD8 coreceptors are not directly involved in the interaction between CD1d and the T cell receptors (TCRs) of iNKT cells, a conspicuous lack of $\mathrm{CD}^{+}{ }^{+}$iNKT cells in mice raised the question of whether $C D 8^{+}$iNKT cells are excluded due to negative selection during their thymic development, or if there is no lineage commitment for the development of murine $\mathrm{CDB}^{+}$iNKT cells. To address this question, we analyzed iNKT cell-specific TCR $V_{\alpha} 14^{+}$transgenic mice, where the $V_{\alpha} 14$ transgene forces the generation of iNKT cells. This allows detailed study of the iNKT cell repertoire. We were able to identify $\mathrm{CDB}^{+}$iNKT cells which respond to the NKT cell-specific glycolipid ligand $\alpha$-galactosylceramide. Unlike conventional iNKT cells, $\mathrm{CD}^{+}{ }^{+}$iNKT cells produce predominantly IFN- $\gamma$ but not IL-4 upon antigen stimulation. We also confirmed the presence of $\mathrm{CD}^{+}{ }^{+}$iNKT cells in wild type mice. Our results suggest that $C D 8^{+}$NKT cells do exist in mice, although their population size is quite small. Their Th1-skewed phenotype might explain why the population size of this subtype needs to be controlled tightly.
\end{abstract}

Keywords: antigens, CD1d; CD8-positive T-lymphocytes; $\alpha$-galactosylceramide; mice, transgenic; natural killer T-cells

\section{Introduction}

Natural killer T (NKT) cells are distinguished from conventional $T$ lymphocytes by their function and $T$ cell receptor (TCR) usage (Bendelac et al., 1997). They are divided by their TCR repertoires into 2 groups, Type I and Type II NKT cells. Both NKT cell types undergo $C D 1 d$-dependent development in the thymus and recognize glycolipid antigens presented on CD1d, a nonpolymorphic class lb molecule. Murine type I NKT cells express an invariant TCR $V_{\alpha} 14$ chain and restricted TCR $V \beta$ chains and are thus called invariant NKT (iNKT) cells, while Type II NKT cells express diverse $V \alpha$ chains (Godfrey et al., 2004). As Type I but not type II NKT cells recognize $\alpha$-galactosylceramide ( $\alpha$-GalCer), they can be detected by using $\alpha$-galCer-loaded CD1d tetramer. Type I NKT (iNKT) cells rapidly produce large amounts of cytokines such as IFN- $\gamma$, IL-4 and IL-10 upon interaction with $\alpha$-GalCer-loaded CD1d (Kronenberg and Gapin, 2002; Godfrey et al., 2004). Due to their ability to produce both Th1 and Th2-type cytokines, NKT cells are believed to play roles not only in tumor rejection and defense against infectious agents but also in the regulation of autoimmunity (Kronenberg and Gapin, 2002).

Like murine iNKT cells, human iNKT cells also use an invariant $V_{\alpha 2} 24$ chain paired with a $V \beta 11$ chain and are activated by glycolipid antigens presented on CD1d. TCR V $\alpha$ chains of human and murine iNKT cells are highly homologous (Lantz and Bendelac, 1994) and they can cross-react to each other's CD1d molecules (Borg et al., 2007). Despite the strong similarity in iNKT cells between the two species, it is generally accepted that mice do not have $\mathrm{CD} 8^{+}$iNKT cells (Bendelac et al., 1997; Kronenberg and Gapin, 2002), while human and macaque iNKT cells are constituted by CD4 single positive, CD8 single positive and CD4/CD8 double negative (DN) cells (Motsinger et al., 2003; Seino and Taniguchi, 2005). The conspicuous lack of $\mathrm{CD}^{+}$iNKT cells in mice might be the result of negative selection during thymic development, lack of lineage commitment for the development of murine $\mathrm{CD} 8^{+}{ }^{+}$NKT cells, or a small population size which might have been previously overlooked. A murine system with a large iNKT cell population 
would help address this question by allowing differentiation of each subtype of iNKT cells.

TCR $V_{\alpha 14}$ transgenic mice $\left(V_{\alpha} 14^{+}\right)$strongly express an invariant TCR $\mathrm{V} \alpha 14$ chain used by invariant NKT cells, thus supporting the development of iNKT cells (Bendelac et al., 1996). Since $\mathrm{V} \alpha 14^{+}$mice produce a large number of iNKT cells, these mice are ideal to analyze the repertoire of iNKT cells.

Through careful analysis of iNKT cells in $\mathrm{V} \alpha 14^{+}$ and wild type (WT) mice, we found, for the first time, that there is indeed lineage commitment toward $\mathrm{CD}^{+}{ }^{\mathrm{iNKT}}$ cells in the murine thymus, and that these cells showed a Th1-skewed phenotype by predominantly producing IFN- $\gamma$ upon $\alpha$-GalCer stimulation.

\section{Results}

\section{The existence of $\mathrm{CD}^{+}{ }^{+}$iNKT cells in $\mathrm{V} \alpha 14^{+}$mice}

To determine the presence of $C D 8^{+}$iNKT cells, we first stained splenocytes and thymocytes in $\mathrm{CD}_{1 \mathrm{~d}^{-/-}}$, WT and $\mathrm{V} \alpha 14^{+}$mice with $\alpha$-GalCer-loaded CD1d dimer and mAbs against TCR $\beta$, CD4 and CD8 $\alpha$. As previously reported (Bendelac et al., 1996), CD1d/ $\alpha$-GalCer dimer ${ }^{+} \mathrm{T}_{\text {T }}$ cells (which indicate iNKT cells) in $\mathrm{V} \alpha 14^{+}$mice were greatly expan-

A
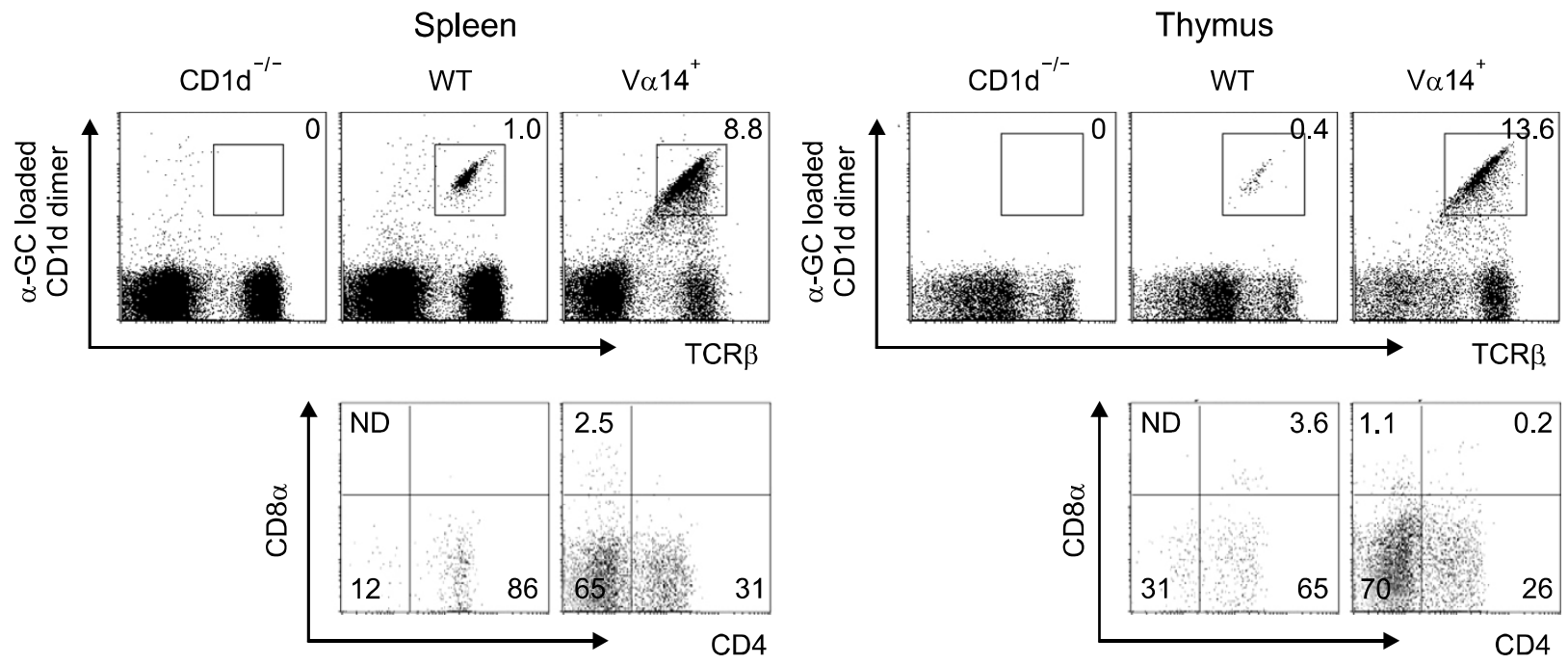

B
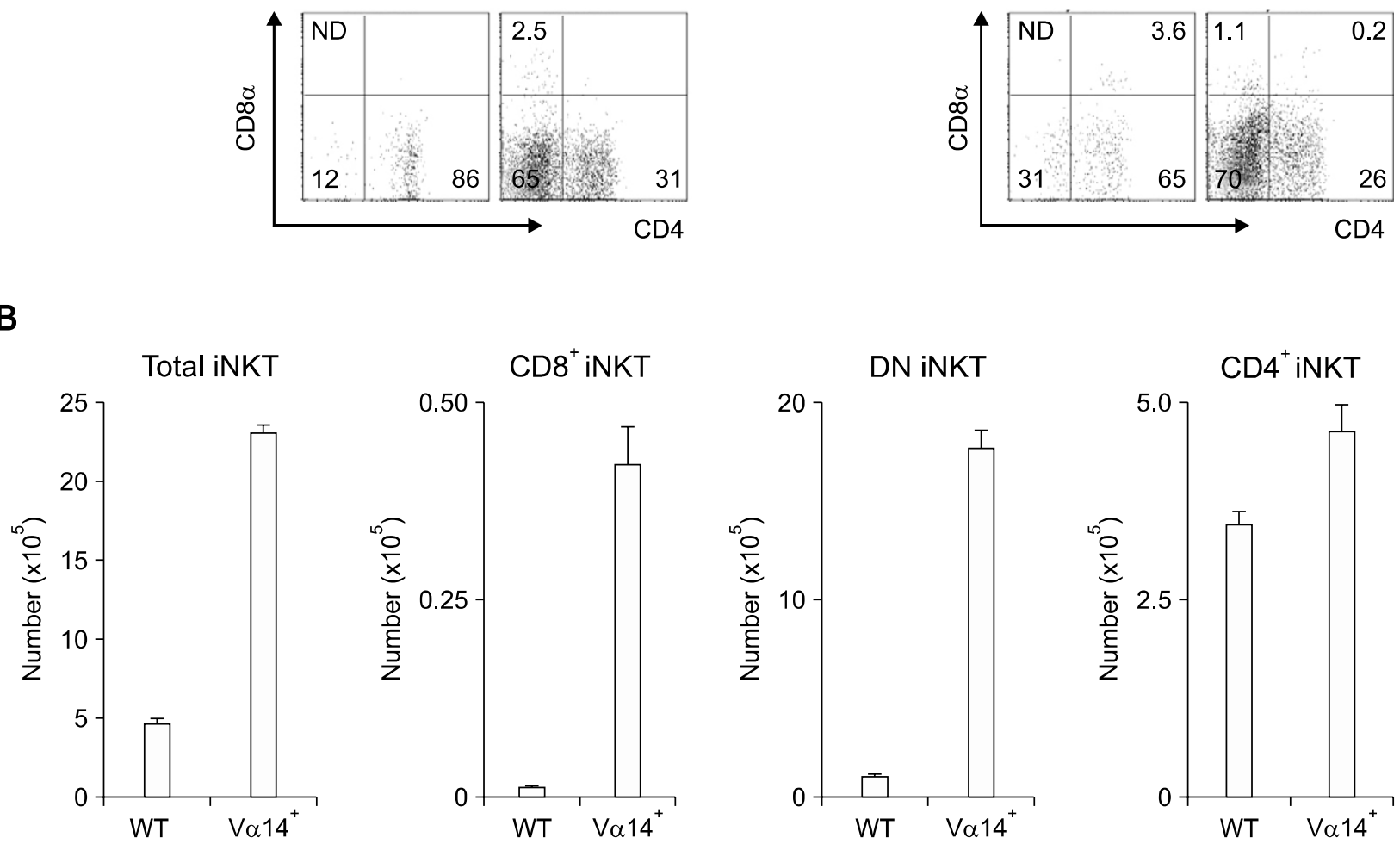

Figure 1. The Existence of $\mathrm{CD} 8^{+}$invariant NKT cells in $\mathrm{V} \alpha 14^{+}$mice. The size of the iNKT cell population (A) in the spleen and thymus from the indicated mice were analyzed as described in Methods. The numbers in the dot plot indicate the percentage of each cell population. Lower panels show the CD4 and CD8 phenotypes of TCR $\beta^{+} \mathrm{CD} 1 \mathrm{~d} / \alpha-$-GalCer dimer ${ }^{+}$cells in each mouse. (B) The absolute number of each iNKT cell subtype in the spleen. Numbers represent mean value \pm SD per spleen. ND means not detected. 
Table 1. iNKT cells in WT and $V_{\alpha} 14^{+}$mice. $^{a}$

\begin{tabular}{llcc}
\hline Phenotype & Organ & WT $(\%)$ & $\mathrm{V} \alpha 14^{+}(\%)$ \\
\hline iNKT & Spleen & $2.69 \pm 0.82$ & $27.7 \pm 5.66^{\star *}$ \\
& Thymus & $2.63 \pm 1.51$ & $26.9 \pm 1.68^{* *}$ \\
CD4 iNKT & Spleen & $2.31 \pm 0.76$ & $7.58 \pm 2.03^{\star *}$ \\
& Thymus & $1.62 \pm 0.58$ & $8.66 \pm 1.24^{\star *}$ \\
CD8 iNKT & Spleen & $<0.02$ & $0.58 \pm 0.25^{\star *}$ \\
& Thymus & $<0.01$ & $0.71 \pm 0.34^{\star *}$ \\
DN iNKT & Spleen & $0.33 \pm 0.14$ & $19.4 \pm 4.26^{* *}$ \\
& Thymus & $0.84 \pm 0.53$ & $16.9 \pm 1.08^{\star *}$ \\
\hline
\end{tabular}

${ }^{a}$ Data show the percentage of each subset of iNKT cells among total splenic and thymic $T$ cells of indicated mice. Data summarized the results of three independent experiments $(n=6-7)$. Data represent the mean values \pm SD. iNKT cells indicated $\alpha$-GalCer/CD1d dimer ${ }^{+}, \mathrm{TCR}^{+}$cells, $\mathrm{DN}$ : $\mathrm{CD} 4 \mathrm{CD} 8$ double negative.

ded compared to WT mice $(8.8 \%$ vs. $1.0 \%$ in the spleen and $13.6 \%$ vs. $0.4 \%$ in the thymus). The number of iNKT cells in liver also expanded up to $30-40 \%$ of total liver $\mathrm{T}$ cells (data not shown). In accordance with the previous report, the relative population size of DN iNKT cells was increased, and the population with a CD4 phenotype was decreased in $\mathrm{V} \alpha 14^{+}$mice compared to WT mice (Table 1). Additionally we were able to clearly detect $\mathrm{CD}^{+}{ }^{+}$iNKT cells in $\mathrm{V} \alpha 14^{+}$mice $(2.5 \%$ in spleen and $1.1 \%$ in thymus, Figure $1 \mathrm{~A}$ and $2 \%$ in liver, data not shown). This subtype of iNKT cells in WT mice was negligible and thus could be considered a non-specific staining. To enumerate the presence of $\mathrm{CD}^{+}$iNKT cells, we next determined the absolute number of each subtype of iNKT cells in WT and $V_{\alpha} 14^{+}$mice. As expected, while the absolute number of CD4 ${ }^{+}$iNKT cells was increased marginally, the absolute number of $\mathrm{CD}^{+}$iNKT cells along with DN iNKT cells in $\mathrm{V} \alpha 14^{+}$mice was greatly increased compared to WT mice (Figure $1 \mathrm{~B})$. Although it has been shown that the majority of iNKT cells in $\mathrm{V} \alpha 14^{+}$have the DN phenotype (Bendelac et al., 1996; Baldwin et al., 2005), the existence of $\mathrm{CD}^{+}$iNKT cells was not clearly appreciated since this subtype has not been recognized in WT mice and their population size even in $\mathrm{V} \alpha 14^{+}$mice was still quite small. However, by careful examination of iNKT cells in $\mathrm{V} \alpha 14^{+}$mice, we found that $\mathrm{CD} 8^{+}$iNKT cells do exist, and there was a substantial increase in the relative ratio and absolute number of $\mathrm{CD} 8^{+}$iNKT cells.

\section{TCR V $\beta$ usage of CD8 ${ }^{+}$iNKT cells}

We next examined TCR V $\beta$ usage of CD8 ${ }^{+}$iNKT cells, since it has been shown that type I iNKT cells express the $V_{\alpha 14}$ chain combined with restricted
$\mathrm{V} \beta$ chains (mainly $\mathrm{V} \beta 8,7$ and 2) (Lantz and Bendelac, 1994; Bendelac et al., 1996). We compared $\mathrm{V} \beta$ repertoires of $\mathrm{CD}^{+}$iNKT and $\mathrm{CD}^{-}$ $\left(\mathrm{CD} 4^{+}\right.$and DN) iNKT cells. Both subtypes of iNKT cells utilized NKT cell-specific $V \beta$ chains. This is quite different from conventional $T$ cells in WT mice, which express a more even distribution from $\mathrm{V} \beta 2$ to $\mathrm{V} \beta 14$, without preference for specific $\mathrm{V} \beta$ chains. $\mathrm{CD}^{+} \mathrm{NKT}$ cells expressed a similar $\mathrm{V} \beta$ repertoire as $\mathrm{CD}^{-}$iNKT cells in $\mathrm{V} \alpha 14^{+}$mice, which consisted of three major families: $V \beta 2, V \beta 7$ and $\vee \beta 8$. However, $V \beta 8$ and 7 usage was lower in $\mathrm{CD}^{+}$than CD8- iNKT cells, and V $\beta 9$ and 14 usage in the spleen was remarkably increased in $C D 8^{+}$ cells (Figure 2). Interestingly, the increase of V $\beta 9$ and 14 has also been reported previously in $\mathrm{V} \alpha 14^{+}$ mice (Wei et al., 2006) (Figure 2). However, since the authors had not clearly distinguished the CD8 ${ }^{+}$ iNKT cell population from the larger population of DN iNKT cells, it was considered to be an idiosyncrasy of the transgenic mice.

\section{Th1-skewed response of $\mathrm{CD}^{+}{ }^{+}$iNKT cells against $\alpha$-GalCer}

It is known that iNKT cells are activated by $\alpha$ GalCer derived from a marine sponge (Bendelac et al., 1997). To analyze functional characteristics of $\mathrm{CD}^{+}$iNKT cells, we first examined cytokine production by iNKT cells upon $\alpha-$ GalCer stimulation. While CD8 $8^{-}$iNKT cells from WT or $\mathrm{V} \alpha 14^{+}$mice showed the typical cytokine production profile of

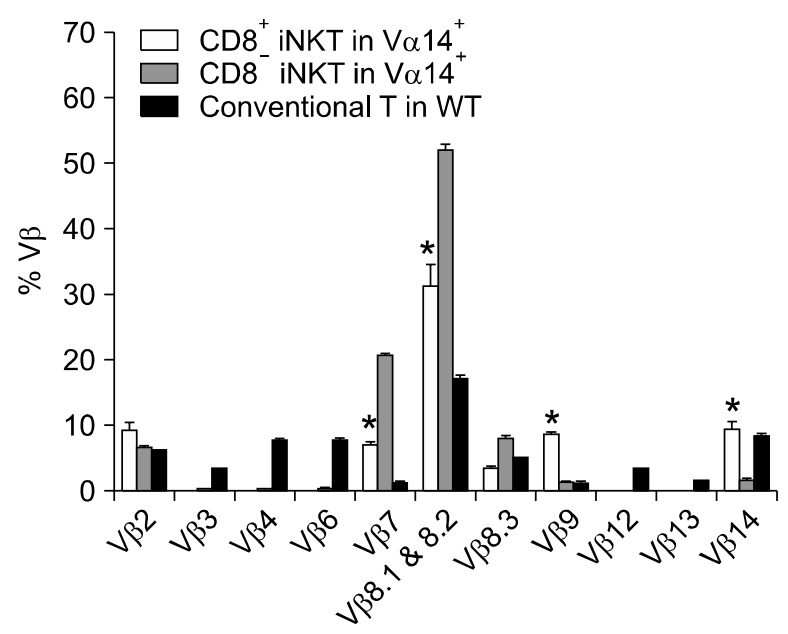

Figure 2. TCR V $\beta$ usage of $C D 8^{+}$invariant NKT cells in $V \alpha 14^{+}$mice Splenocytes from the indicated mice were stained with CD1d/ $\alpha-G a l C e r$ dimer and mAbs against TCR $\beta, C D 8 \alpha$ and the V $\beta$ TCR screening panel. The bar chart shows the mean percentage of each subtype of $V \beta$ positive T cells $( \pm S D)$ among the indicated cells. The percentages represent mean value $\pm S D$ per spleen. 
A
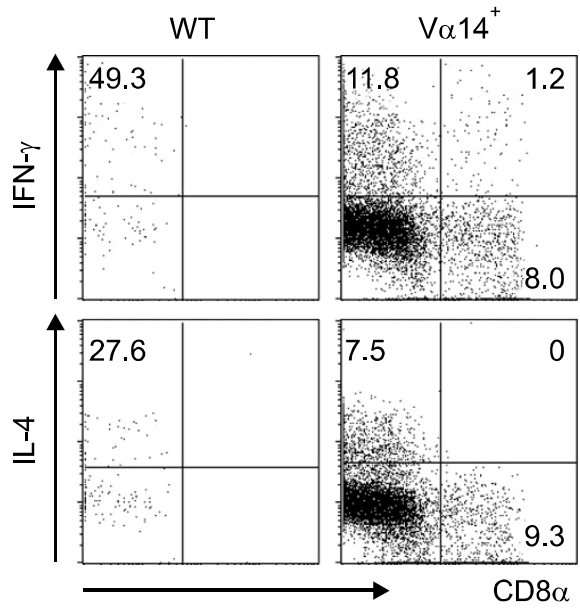

B
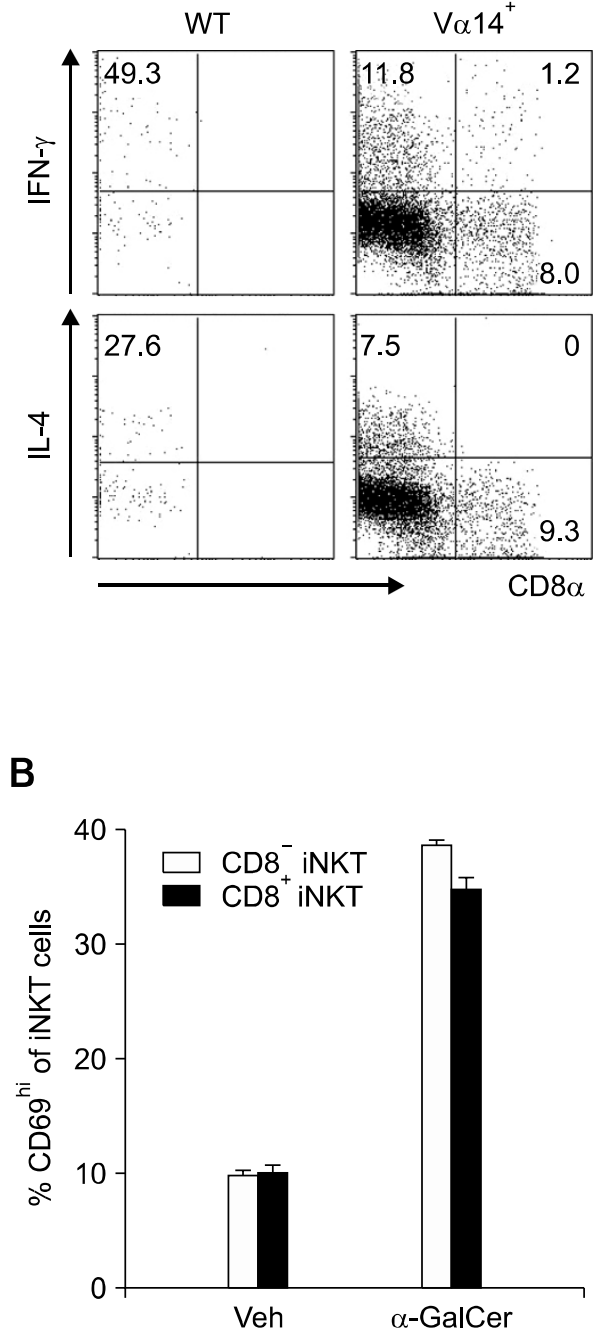

C

phocytes

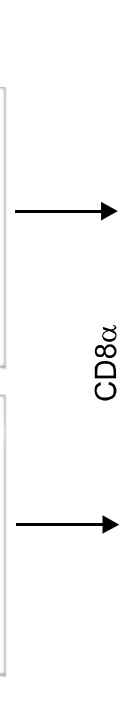

$\mathrm{CD}^{-}{ }^{-}$dimer $^{+}$ $\mathrm{TCR}^{+}{ }^{+}$cells
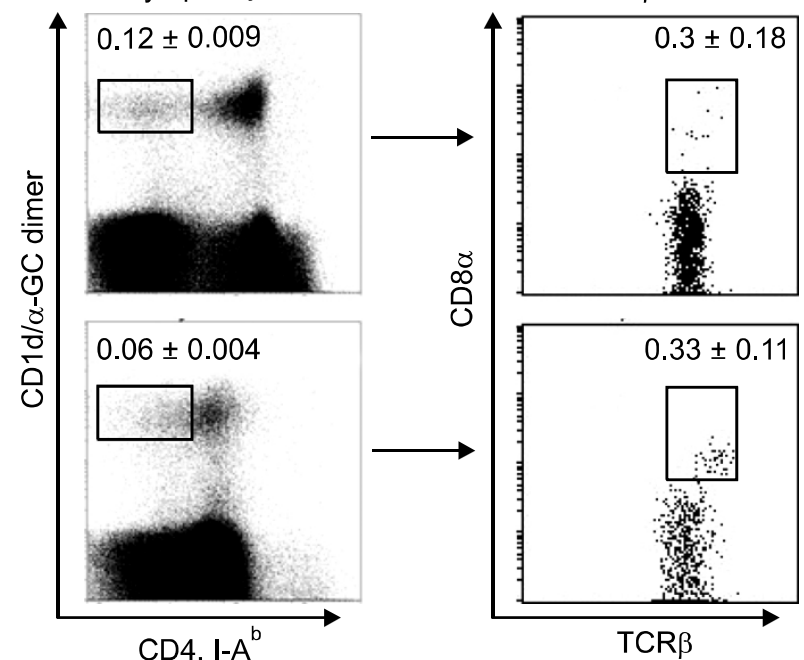

Spleen

Thymus

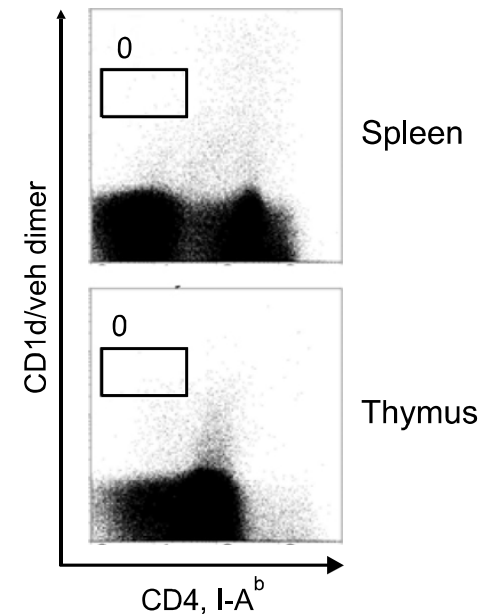

Figure 3. $\mathrm{CD}^{+}$invariant NKT cells in $\mathrm{V} \alpha 14^{+}$mice reveal a Th1-skewed phenotype. Splenocytes from the indicated mice were co-cultured with DCs pulsed with $100 \mathrm{ng} / \mathrm{ml} \alpha$-GalCer for $6 \mathrm{~h}$. (A) Percentage of IFN- $\gamma$ and IL-4-secreting cells among gated iNKT cells. (B) Percentage of CD69 ${ }^{\text {hi }}$ cells in the indicated iNKT cells. The bar chart represents mean value \pm SD. (C) Splenocytes and thymocytes from WT mice ( $n=3$ ) were stained with $\mathrm{CD} 1 \mathrm{~d} / \alpha-$ GalCer dimer along with mAbs against CD4, CD8, TCR $\beta$ and I- $\mathrm{A}^{\mathrm{b}}$. Vehicle loaded mCD1d-dimer was used as a negative control. After recording more than one million events, CD1d/ $\alpha$-GalCer dimer ${ }^{+}$CD4 ${ }^{-}-A^{b-}$ cells were plotted against TCR $\beta$ and CD8 $\alpha$ expression. Antibody against I- $A^{b}$ was used to exclude non-T cell populations in the analysis. The numbers on the figure represent mean percentage \pm SD of marked cells from three WT mice. The data shown are representatives of two independent experiments with similar result.

iNKT cells (both IL-4 and IFN- $\gamma$ ), $\mathrm{CD}^{+}{ }^{+}$iNKT cells mainly produced IFN- $\gamma$ but not IL-4 (Figure 3A). These data suggest that $\mathrm{CD} 8^{+}$iNKT cells probably have a more Th1-skewed phenotype than conventional CD8- iNKT cells.

Secondly, we examined the activation status of NKT cells by measuring CD69 on NKT cells upon $\alpha$-GalCer stimulation, since it was previously reported that $\alpha$-GalCer stimulation of NKT cells leads to significant up-regulation of CD69 on NKT cells (Testi et al., 1994; Vilanova et al., 1996). CD8 ${ }^{+}$
iNKT cells up-regulated CD69 as much as CD8 iNKT cells upon $\alpha$-GalCer stimulation, suggesting that $\mathrm{CD}^{+}$iNKT cells have the same activation potency as CD8 ${ }^{-}$iNKT cells (Figure $3 \mathrm{~B}$ ).

\section{Presence of $\mathrm{CD}^{+}$iNKT cells in the wild type mouse}

Since we confirmed the presence of $C D 8^{+}$iNKT cells in $\mathrm{V} \alpha 14^{+}$mice, we decided to re-evaluate WT mice for the presence of $\mathrm{CD}^{+}$iNKT cells, which might have been ignored in other studies because 
of their low numbers. We recorded a large number of events (more than $1.5 \times 10^{6}$ cells) in the FACS analysis for iNKT cells and found clearly distinguishable $\mathrm{CD}^{+}$iNKT cells in the spleen and thymus from wild type mice, although their population size was very limited (Figure $3 \mathrm{C}$ ). These results disprove the idea that there is no lineage commitment to $\mathrm{CD}^{+}{ }^{+} \mathrm{NKT}$ cells during their development.

\section{Discussion}

CD1d-dependent NKT cells appear to be CD4 single positive or CD4/CD8 DN in terms of their coreceptor expression, at least in mice. Because invariant TCRs of NKT cells recognize glycolipid antigens presented on CD1d, a MHC I-like molecule, coreceptor CD4 on the iNKT cells does not have any specific function for CD1d/antigen recognition, although CD4 and DN NKT cells can be functionally and developmentally distinctive (Gumperz et al., 2002; Benlagha et al., 2005). However, the conspicuous lack of CD1d-dependent $\mathrm{CD}^{+}$ NKT cells despite of the presence CD $4^{+}$NKT cells in mice provoked the question of whether $\mathrm{CD}^{+}$ NKT cells undergoing selection are too scarce to be detected or if NKT cells do not express CD8 for another reason. One common explanation is that CD8 provides too strong affinity for the recognition of CD1d/antigen by the TCRs of iNKT cells, which thus induces negative selection during thymic development of iNKT cells (Ashton-Rickardt et al., 1994; Bendelac et al., 1994; Kronenberg, 2005). However, there has been no experimental proof for the negative selection of this subtype of iNKT cells in mice. Although there were reports of the existence of $\mathrm{CD}^{+} \mathrm{NK} 1.1^{+} \alpha \beta \mathrm{T}$ cells in mice, these cells are not CD1d-dependent (Hammond et al., 1999; Emoto et al., 2000). Unlike CD1d-dependent NKT cells, which have TCR repertoires restricted to $\mathrm{V} \alpha 14$, murine $\mathrm{CD} 8^{+} \mathrm{NK} 1.1^{+} \mathrm{TCR} \beta^{+}$cells have variant $V_{\alpha}$ chains (Eberl et al., 1999). Further questions arise from the fact that there are CD1d-dependent $\mathrm{CD}^{+}$NKT cells in humans (Takahashi et al., 2002).

To address the question whether murine iNKT cells contain a $\mathrm{CD} 8^{+}$subtype, we used the $\mathrm{V} \alpha 14^{+}$ mouse, which has forced expression of the invariant NKT cell receptor $\mathrm{V} \alpha 14$. Our data show that iNKT cells were expanded to up to $28 \%$ of total T cells in the spleen of $\mathrm{V} \alpha 14^{+}$mice, whereas iNKT cells normally constitute less than $2.7 \%$ of splenic $\mathrm{T}$ cells in the WT mouse. Thus the $\mathrm{V} \alpha 14^{+}$mouse is an optimal model for the discovery of a rare population of iNKT cells. We identified $C D 8^{+}$iNKT cells in $\mathrm{V} \alpha 14^{+}$mice. Even more surprisingly, we were able to detect this population in the wild type mouse by recording more than one million events of FACS staining in both the spleen and thymus. Our data clearly show that CD8 ${ }^{+}$NKT cells exist as a subset of iNKT cells, although the population size is quite small. This disproves the idea that there is no lineage commitment to $\mathrm{CD}^{+} \mathrm{NKT}$ cells during their development.

CD1d-dependent iNKT cells, defined as $\alpha$-GalCer/CD1d dimer ${ }^{+}$cells, in $\mathrm{V} \alpha 14^{+}$mice showed a dramatic increase in the absolute number and relative ratio of $\mathrm{CD}^{+}{ }^{+} \mathrm{iNKT}$ cells compared with WT mice. CD8 ${ }^{+}$iNKT cells from $\mathrm{V} \alpha 14^{+}$mice secreted only IFN- $\gamma$ upon in vitro $\alpha$-GalCer activation, unlike CD8 ${ }^{-}$NKT cells from WT or $\mathrm{V}_{\alpha 14^{+}}$mice, and they showed similar or slightly higher levels of CD69 up-regulation compared to CD8- iNKT cells. Consistent with these results, it has been reported that human CD4 $4^{-}$NKT cells, especially CD8 ${ }^{+}$NKT cells, secrete IFN- $\gamma$ but not IL-4 after activation (Gumperz et al., 2002; Lee et al., 2002). This study provides the first in vivo evidence that natural $\mathrm{V} \alpha 14^{+} \mathrm{CD}^{+}$iNKT cells indeed exist in the WT mouse, and they can be expanded by forced expression of the TCR $\mathrm{V}_{\alpha 14^{+}}$transgene. Furthermore, we found that these $\mathrm{CD}^{+}$iNKT cells have extreme Th1-skewed phenotypes. This extreme phenotype of $\mathrm{CD}^{+}$iNKT cells might explain why the number of this subtype is kept low. In other word, it is possible that the interaction between TCR of murine CD8 ${ }^{+}$iNKT cells and mCD1d during thymic development is stronger than the interaction of human $\mathrm{CD}^{+}{ }^{+} \mathrm{iNKT}$ cells and hCD1d. The intrinsic strong interaction affinity between murine $\mathrm{CD} 8^{+}$ iNKT cells and CD1d may induce either negative selection of murine $\mathrm{CD} 8^{+}$iNKT cells or positive selection of Th1-skewed CD8 ${ }^{+}$iNKT cells (though the frequency is low) depending on the natural antigens presented by mCD1d.

It remains to be determined whether there is not enough positive selection for $\mathrm{CD}^{+}$iNKT cells or if there is strong and highly specific negative selection for $\mathrm{CD}^{+}$iNKT cells by CD1d. It will be of great interest to clarify which cells are responsible for the positive (or negative) selection of $C D 8^{+}$iNKT cells.

\section{Methods}

\section{Mice}

C57BL/6 wild type (WT) mice were purchased from The Jackson Laboratory. CD $1 \mathrm{~d}^{-/}$and TCR $\mathrm{V} \alpha 14^{+}$transgenic $\left(\mathrm{V} \alpha 14^{+}\right)$mice were provided by Dr. A. Bendelac (University of Chicago, Chicago, IL).

All mice used in this study had a C57BL/6 background, 
and were raised in a specific pathogen-free environment at Korea University and were used at 6-8 wk of age unless otherwise specified. The experimental protocols adopted in this study were approved by the Institutional Animal Care and Use Committee of Korea University.

\section{FACS analysis}

Cells were pre-incubated with an anti-FcyRII/III mAb (2.4G2) and then labeled for 30 min with the appropriate mAbs. The following mAbs were used: fluorescein isothiocyanate (FITC) conjugated anti-CD4 (clone RM4-5), cychrome (CYC) conjugated anti-CD8 $\alpha$ (clone 53-6.7), allophycocyanin (APC) conjugated anti-TCR $\beta$ (clone H57), APC conjugated anti-IL-4 (clone 11B11) and -IFN- $\gamma$ (XMG1.2) (all from BD PharMingen).

CD1d Dimer $X$ was purchased from BD Biosciences and $\alpha$-GalCer was provided by Dr. Bendelac. CD1d/ $\alpha-G a l C e r$ dimer was prepared according to the manufacturer's protocol.

TCR V $\beta$ usage by NKT cells was analyzed among CD1d/ $\alpha$-GalCer-dimer ${ }^{+}$cells with a mouse V $\beta$ TCR screening panel (BD biosciences). The stained cells were then analyzed on a FACSCalibur using CellQuest software (both BD Biosciences). Figures with panel sets depict analyses from the same experiment to allow for direct comparison of fluorescence intensity.

\section{DC sorting}

Splenic DCs were obtained from naive mice via MACS using magnetic bead-conjugated anti-CD11c mAb (Miltenyi Biotec) in accordance with the manufacturer's instructions.

\section{NKT cell activation}

The cell culture medium used in this study was RPMI 1640 complete medium (Life Technologies, Grand Island, NY) containing $10 \%$ heat-inactivated FBS (Hyclone, Logan, UT) supplemented with $2 \mathrm{mM}$ sodium bicarbonate, $2 \mathrm{mM}$ L-glutamine, $5 \mu \mathrm{M} \beta$-mercaptoethanol, $10 \mu \mathrm{g} / \mathrm{ml}$ gentamicin, $50 \mathrm{U} / \mathrm{ml}$ penicillin and $50 \mu \mathrm{g} / \mathrm{ml}$ streptomycin (all from Life Technologies). For NKT cell activation assays, DCs were used as antigen presenting cells. DCs were pulsed for $4 \mathrm{~h}$ at $37^{\circ} \mathrm{C}$ with $\alpha-G a l C e r$ or vehicle (Veh) and then extensively washed before being plated at $5 \times 10^{4}$ cells/well. Whole splenocytes were seeded at $5 \times 10^{5}$ cells/well in a 96-well plate and then cultured for $6 \mathrm{~h}$ with Golgi stop (BD PharMingen).

\section{Analysis of intracellular cytokine production}

To determine intracellular cytokine levels, cells cultured for $6 \mathrm{~h}$ with Golgi stop (BD PharMingen) were initially stained with the appropriate mAbs, fixed and permeabilized with Cytofix/Cytoperm solution (BD PharMingen) and finally stained with APC-conjugated anti-IL-4 or anti-IFN- $\gamma$ mAbs for $45 \mathrm{~min}$ on ice. The percentage of cells expressing intracellular IL-4 or IFN- $\gamma$ was determined via flow cytometry (FACSCalibur).

\section{Statistical analysis}

Student's $t$ tests were used to determine statistical significance between the two groups. Throughout the text, figures, table and legends, the following symbols were used to denote statistical significance: ${ }^{*}, P \leq 0.0001$ or $P$ $\leq 0.001 ;{ }^{*}, P \leq 0.01$.

\section{Acknowledgements}

The authors thank Dr. A. Bendelac for the generous gift of transgenic animals and $\alpha$-GalCer. This research was supported by Basic Science Research Program through the National Research Foundation of Korea (NRF) (20090081330) and Korea Biotech R\&D Group of Nextgeneration growth engine project (F104AC010002-08A0301-00230) funded by the Ministry of Education, Science and Technology.

\section{References}

Ashton-Rickardt PG, Bandeira A, Delaney JR, Van Kaer L, Pircher HP, Zinkernagel RM and Tonegawa S. Evidence for a differential avidity model of $\mathrm{T}$ cell selection in the thymus. Cell 1994;76:651-63

Baldwin TA, Sandau MM, Jameson SC and Hogquist KA. The timing of TCR alpha expression critically influences T cell development and selection. J Exp Med 2005;202:111-21

Bendelac A, Killeen N, Littman DR and Schwartz RH. A subset of CD4+ thymocytes selected by MHC class I molecules. Science 1994;263:1774-8

Bendelac A, Hunziker RD and Lantz O. Increased interleukin 4 and immunoglobulin $\mathrm{E}$ production in transgenic mice overexpressing NK1 T cells. J Exp Med 1996;184:1285-93

Bendelac A, Rivera MN, Park SH and Roark JH. Mouse CD1-specific NK1 T cells: development, specificity, and function. Annu Rev Immunol 1997;15:535-62

Benlagha K, Wei DG, Veiga J, Teyton L and Bendelac A. Characterization of the early stages of thymic NKT cell development. J Exp Med 2005;202:485-92

Borg NA, Wun KS, Kjer-Nielsen L, Wilce MC, Pellicci DG, Koh R, Besra GS, Bharadwaj M, Godfrey DI, McCluskey J and Rossjohn J. CD1d-lipid-antigen recognition by the semiinvariant NKT T-cell receptor. Nature 2007;448:44-9

Eberl G, Lees R, Smiley ST, Taniguchi M, Grusby MJ and MacDonald HR. Tissue-specific segregation of CD1ddependent and CD1d-independent NK T cells. J Immunol 1999;162:6410-9

Emoto M, Zerrahn J, Miyamoto M, Perarnau B and Kaufmann $\mathrm{SH}$. Phenotypic characterization of CD8(+)NKT cells. Eur J Immunol 2000;30:2300-11

Godfrey DI, MacDonald HR, Kronenberg M, Smyth MJ and Van Kaer L. NKT cells: what's in a name? Nat Rev Immunol 2004;4:231-7

Gumperz JE, Miyake S, Yamamura T and Brenner MB. Functionally distinct subsets of CD1d-restricted natural killer $\mathrm{T}$ cells revealed by CD1d tetramer staining. J Exp Med 


\section{2;195:625-36}

Hammond KJ, Pelikan SB, Crowe NY, Randle-Barrett E, Nakayama T, Taniguchi M, Smyth MJ, van Driel IR, Scollay R, Baxter AG and Godfrey DI. NKT cells are phenotypically and functionally diverse. Eur J Immunol 1999;29:3768-81

Kronenberg M. Toward an understanding of NKT cell biology: progress and paradoxes. Annu Rev Immunol 2005;23:877900

Kronenberg M and Gapin L. The unconventional lifestyle of NKT cells. Nat Rev Immunol 2002;2:557-68

Lantz $O$ and Bendelac $A$. An invariant T cell receptor alpha chain is used by a unique subset of major histocompatibility complex class I-specific CD4+ and CD4-8- T cells in mice and humans. J Exp Med 1994;180:1097-106

Lee PT, Benlagha K, Teyton L and Bendelac A. Distinct functional lineages of human V(alpha)24 natural killer T cells. J Exp Med 2002;195:637-41

Motsinger A, Azimzadeh A, Stanic AK, Johnson RP, Van Kaer $L$, Joyce $S$ and Unutmaz D. Identification and simian immunodeficiency virus infection of CD1d-restricted macaque natural killer T cells. J Virol 2003;77:8153-8

Seino $\mathrm{K}$ and Taniguchi M. Functionally distinct NKT cell subsets and subtypes. J Exp Med 2005;202:1623-6

Takahashi T, Chiba S, Nieda M, Azuma T, Ishihara S, Shibata Y, Juji T and Hirai H. Cutting edge: analysis of human V alpha $24+C D 8+N K T$ cells activated by alpha-galactosylceramide-pulsed monocyte-derived dendritic cells. J Immunol 2002; 168:3140-4

Testi R, D'Ambrosio D, De Maria R and Santoni A. The CD69 receptor: a multipurpose cell-surface trigger for hematopoietic cells. Immunol Today 1994;15:479-83

Vilanova M, Tavares D, Ferreira P, Oliveira L, Nobrega A, Appelberg $\mathrm{R}$ and Arala-Chaves M. Role of monocytes in the up-regulation of the early activation marker CD69 on B and $T$ murine lymphocytes induced by microbial mitogens. Scand J Immunol 1996;43:155-63

Wei DG, Curran SA, Savage PB, Teyton L and Bendelac A. Mechanisms imposing the Vbeta bias of Valpha14 natural killer $T$ cells and consequences for microbial glycolipid recognition. J Exp Med 2006;203:1197-207 